Máximo García Fernández (dir.), Cultura material y vida cotidiana moderna: escenarios Madrid: Sílex Ediciones, 2013. 306 pp.

\title{
SOBRE LA VIDA COTIDIANA Y LA CULTURA MATERIAL EN EL ANTIGUO RÉGIMEN
}

\author{
Ana María Fernández García* \\ Universidad de Oviedo
}

Se trata de un libro colectivo integrado por dieciséis trabajos científicos con distintos objetos de estudio y concreciones geográficas diferentes dentro de la península ibérica, que se aglutinan en un esfuerzo común por identificar la cultura material de cotidianeidad en el Antiguo Régimen. A pesar del aparente carácter heterogéneo de las propuestas, el hilo argumental es muy claro, pues se articula alrededor de los objetos. Conocidos éstos básicamente a través de las fuentes documentales, sirvieron a los intereses cotidianos de la sociedad moderna. Objetos de uso habitual, unos prácticos, y otros simbólicos, unos afectos al espacio doméstico y otros concebidos para ser valorados por "el otro", unos corrientes y otros importados, sin embargo, todos ellos están relacionados con las maneras de vivir o con los gustos y modas imperantes en cada momento.

Aunque la lectura de esta obra es recomendable para todos los trabajos, por el carácter de esta revista dedicada al mueble y al objeto decorativo, quisiera reseñar el interés de algunas aportaciones. Muy revelador es el capítulo dedicado a la "Documentación de bienes difuntos y el estudio de la vida cotidiana", de María del Mar Barrientos Márquez y María Magdalena Guerrero Cano. En él se analizan lo que se denomina "bienes difuntos", esto es, las pertenencias dejadas en Indias por los españoles o extranjeros fallecidos en ultramar. A lo largo del trabajo se diseccionan los mecanismos de estos expedientes (testamentos, inventarios, tasaciones, almonedas,...) para entender los diferentes niveles de información que arrojan sobre la vida cotidiana. Los inventarios, por ejemplo, permiten distinguir los bienes que el difunto había llevado de Europa de los enseres conseguidos en Indias, o la relación entre la profesión del finado y los muebles que poseía (papeleras, baúles o cajas en el caso de los comerciantes). Estas fuentes documentales, aparentemente tan poco trascendentes desde el punto de vista de una historia política, se vislumbran como una fuente inagotable de información acerca de modelos de vida y de la interacción cultural entre los emigrantes y su entorno.

Otro trabajo sugerente para los objetivos de esta revista es el de Juan Manuel Bartolomé Bartolomé, "Patrimonios, condiciones de vida y consumo. La burguesía administrativa y las profesiones liberales en la ciudad de León. 1700-1850". Es un 
trabajo modélico en tanto que ofrece unas pautas de consumo y un retrato de la vida cotidiana de la burguesía leonesa a través fundamentalmente de los inventarios post mortem. Y, aunque en general no hay sorpresas sobre los ajuares de este sector social, sí se comprueban datos interesantes para la historia de la cultura material, como la aparición de "cubiertos de moda", o tenedores a mediados del siglo XVIII, o la proliferación en la segunda mitad del setecientos de un mobiliario que sustituye al tradicional estrado, con sofás, mesas de juego o cómodas. Interesante es también que frente a la tradicional decoración de los espacios domésticos con cuadros religiosos, aparezcan también cornucopias, algunas imágenes de animales o de reyes o que, ya avanzado el siglo XIX, haga su aparición en estos interiores burgueses el reloj de pared. Finalmente, el trabajo demuestra la lógica relación entre niveles de renta y la posesión de objetos de oro y plata, mientras que (y esto sí que plantea una novedad metodológica) el mobiliario está vinculado más a la profesión del poseedor que a su riqueza patrimonial.

El estudio de Rosa María Dávila Corona, "Los patrimonios de la burguesía comercial vallisoletana, 1760-1860”, es de alguna manera complementario del anterior, pues analiza el mismo espectro social y cronológico con las parecidas fuentes documentales. Pero los resultados son elocuentemente diferentes. En primer lugar porque la documentación le permite diferenciar claramente las distintas piezas de la vivienda urbana, su disposición en altura y su distribución interna y la especialización de los espacios en el discurrir de la vida familiar. Además los acervos de bienes parecen a priori mucho más ricos, lo que posibilita la identificación precisa incluso del menaje de mesa. Nos interesa sobremanera la curiosa convivencia de arcas, baúles y arcones tradicionales con nuevos muebles de guardar, como los armarios roperos, sobre todo desde 1810, o los escaparates para exponer la vajilla familiar, o la cohabitación -y nunca mejor dicho- de las camas de tablas y cordeles, con las de tipo imperio.

En el caso del trabajo "Vivienda e interiores domésticos en el Madrid ilustrado", de Natalia González Heras, la riqueza de las fuentes permite establecer un retrato muy fiable de los interiores domésticos donde en el siglo XVIII se han introducido valores como comodidad, confort e intimidad. En este caso, la segregación de espacios es patente, aislando los ámbitos públicos de los privados. Se analiza además un apartado poco tratado en la mayoría de los estudios, como es el tema de la iluminación y la ventilación, o la calidez confortable que proporcionaban los distintos artilugios de calefacción.

Sería excesivamente prolijo profundizar en otros trabajos incluidos en el volumen en esta modesta reseña, pero creo que el trabajo de Máximo García Fernández, "Cultura material, consumo, moda e identidades sociales: la almoneda de bienes" no puede obviarse. Es una investigación modélica en las aportaciones generales de carácter metodológico, en la riqueza de las fuentes y, sobre todo, en la meticulosa introspección de los datos proporcionados. Las almonedas no sólo detallan los conjuntos, sino los valores de tasación y remate de las piezas. Como sucede con las subastas actuales, los remates ofrecen el valor real del mercado, lo que éste está dispuesto a pagar, por encima o por debajo, del precio estipulado por el vendedor. Establece además un perfil del comprador de este mercado secundario, y deja -como todas las buenas investigaciones- muchos interrogantes para seguir trabajando en este ámbito. Por otra parte, las tablas incorporadas al texto aportan además una valiosa información complementaria, que hace apreciar la supremacía en tales intercambios de los textiles, especialmente de la ropa de cama. 
En resumen, la obra coral Cultura material y vida cotidiana moderna: escenarios, está llamada a convertirse en una obra de referencia para los estudios futuros sobre cultura material en el Antiguo Régimen. Demuestra además la importancia de trabajar en grupos amplios, con enfoques interdisciplinares y complementarios, para conseguir una reconstrucción completa de los escenarios diarios del pasado. Igualmente ejemplifica cómo el estudio histórico de los objetos puede arrojar un mayor conocimiento de la vida cotidiana, ésa que ha quedado excluida de la historia durante muchos años.

Fecha de recepción: 5 de noviembre de 2013

Fecha de revisión: 11 de noviembre de 2013

Fecha de aceptación: 15 de noviembre de 2013 